Portland State University

PDXScholar

2013

\title{
A More Perfect Commodity: Bottled Water, Global Accumulation, and Local Contestation
}

\author{
Daniel Jaffee \\ Portland State University, jaffee@pdx.edu \\ Soren Newman \\ University of Idaho
}

Follow this and additional works at: https://pdxscholar.library.pdx.edu/soc_fac

Part of the Place and Environment Commons, Politics and Social Change Commons, and the Rural Sociology Commons

Let us know how access to this document benefits you.

\section{Citation Details}

Published as: Jaffee, D. and Newman, S. (2013), A More Perfect Commodity. Rural Sociol, 78: 1-28. https://doi.org/10.1111/j.1549-0831.2012.00095.x

This Post-Print is brought to you for free and open access. It has been accepted for inclusion in Sociology Faculty Publications and Presentations by an authorized administrator of PDXScholar. Please contact us if we can make this document more accessible: pdxscholar@pdx.edu. 


\title{
A MORE PERFECT COMMODITY: \\ BOTTLED WATER, GLOBAL ACCUMULATION, AND LOCAL CONTESTATION \\ Daniel Jaffee and Soren Newman
}

This is the Accepted Manuscript (Author's post-print) of an article published in the journal Rural Sociology. Available online: https://doi.org/10.1111/j.1549-0831.2012.00095.x

Citation: Daniel Jaffee ${ }^{1}$ and Soren Newman. 2013. "A More Perfect Commodity: Bottled Water, Global Accumulation, and Local Contestation." Rural Sociology 78(1): 1-28.

\begin{abstract}
Bottled water sits at the intersection of debates regarding the social and environmental effects of the commodification of nature and the ways neoliberal globalization alters the provision of public services. Utilizing Polanyi's concept of fictitious commodities and Harvey's work on accumulation by dispossession, this article traces bottled water's transformation from elite niche item to a product consumed by three-fourths of U.S. households. Drawing upon ethnographic research with participants in two cases of proposed spring water extraction from rural communities by industry leader Nestlé Waters, we make two principal arguments. First, the case of bottled water necessitates a reevaluation of existing theoretical frameworks regarding water privatization and commodification. Municipal tap water networks pose substantial barriers to capital accumulation, leading one influential scholar to frame water as an "uncooperative commodity." However, bottled water's characteristics enable it to evade many of these constraints, rendering it a "more perfect commodity" for accumulation. Second, expansion of the market good of bottled water alters the prospects for the largely publicly provided good of tap water. We conclude that the growth of this relatively new commodity represents a more serious threat to the project of universal public drinking water provision than that posed by tap water privatization.
\end{abstract}

\footnotetext{
${ }^{1}$ Department of Sociology, Portland State University, Portland, OR, USA. Email: jaffee@pdx.edu
} 


\section{A MORE PERFECT COMMODITY: \\ BOTTLED WATER, GLOBAL ACCUMULATION, AND LOCAL CONTESTATION \\ Daniel Jaffee and Soren Newman}

"The biggest enemy is tap water."

-Robert S. Morrison, Chairman, PepsiCo North American Beverage and Food Division*

"When we're done, tap water will be relegated to showers and washing dishes."

-Susan Wellington, President, Quaker Oats U.S. Beverage Division*

Thirty years ago, the prospect of a large segment of the population shunning tap water and families spending hundreds of dollars or more annually on bottled water would have struck many people as ludicrous. Yet today, bottled water is second only to soft drinks as the world's most-consumed beverage, surpassing 56 billion gallons in 2010. U.S. consumers collectively guzzled 8.7 billion gallons, or 28 gallons per capita, below Italy at 49 gallons and Mexico at 64 gallons (Rodwan 2011). Much of that growth has come at the expense of the tap: since 1980, per capita consumption of tap water in the United States has fallen by 36 gallons (Gleick 2010). As the epigrams above indicate, the bottled water and beverage industries are engaged in a public relations battle against municipal tap water, one that has proved strikingly effective.

The commodity of bottled water sits intriguingly at the intersection of current debates regarding the appropriate boundary between the private and public spheres (e.g., Laxer and Soron 2006); the ways neoliberal globalization has altered nation-states and the social compact regarding provision of basic public services (e.g., Dilworth 2007; McMichael 2011); the construction of identity through consumption (e.g., Wilk 2006) and the social and ecological implications of the commodification or "neoliberalization" of nature (e.g., Castree 2008).

\footnotetext{
${ }^{*}$ Quoted in Gleick 2010.
} 
The riddles posed by the meteoric rise of this commodity - for which consumers pay thousands of times more per gallon than tap water (Environmental Working Group 2008) to consume a product that is less regulated, can contain more toxic substances, and uses over 1,000 times more energy (Gleick and Cooley 2009; Parag and Roberts 2009; Stephenson 2009), yet (at least in most of the global North) is largely unnecessary for meeting physical need-presumably would be of great interest to social scientists. Yet despite bottled water's dramatic growth over the past quarter century, its present ubiquity, and the not insignificant local contestation it has generated, scholarly attention to this phenomenon has been surprisingly sparse. This is true not only regarding its social, political-economic, and environmental effects, but also the ways that bottled water parallels and diverges from the process of privatization and commodification of municipal drinking water systems in the global South and North. That latter phenomenon-the privatization of tap water-has received far greater scrutiny, in particular the efforts by transnational water corporations to open municipal public water systems in the global South to private ownership and management, and the often dramatic protests that have accompanied this phenomenon (e.g., Bakker 2010; Goldman 2005). Bottled water extraction, as we explain below, represents a distinct (though related) set of processes, and the industry is dominated by a different group of multinational firms.

Sociologists and other observers of such instances of privatization have found utility in a range of analytical frameworks, among these David Harvey's prominent notion of "accumulation by dispossession," and have generated a substantial body of literature focusing on water as an exemplar (e.g., Ahlers 2010; Bakker 2005; Castro 2007; Goldman 2007; Roberts 2008; Spronk and Webber 2007; Swyngedouw 2005). Yet a key issue remains undertheorized: the differential barriers to accumulation that are posed by distinct forms of what is ostensibly a single resource. 
By extending this analysis to incorporate the complex relationship between bottled and municipal water, the present article aims to contribute to a more nuanced debate regarding the manner in which commodification, accumulation and social contestation intersect.

In the following section, we chart key debates over the commodification and enclosure of nature, drawing parallels to scholarship on the political economy of food systems regarding biotechnology. We briefly synopsize the issues raised by the privatization of drinking water globally, examining both the contestation it has engendered and the barriers it has posed to capital accumulation. The third section focuses on bottled water specifically, charting its meteoric rise from an elite niche product to a $\$ 65$ billion annual market. We trace the growing opposition to bottled water extraction in the United States as well as the industry's changing strategies in response to this activism. The fourth section examines these issues through ethnographic research on two specific instances of local contestation over bottled water. A fifth section evaluates the ways that bottled water diverges conceptually from tap water, but how the expansion of the former is intimately linked to the fortunes of the latter.

We make two principal arguments in this article. First, we contend that bottled water represents a challenge to the primary ways that scholars have so far conceptualized the privatization and commodification of water. Specifically, bottled water does not present many of the barriers to capital accumulation posed by tap water networks, in contrast with Bakker's (2005) influential framing of water as an "uncooperative commodity." Many observers confirm that the privatization of municipal (tap) water systems around the world has encountered significant obstacles to capital accumulation (Bakker 2005; Loftus 2009; Swyngedouw 2005). However, bottled water's material traits—as well as the technological and political-economic transformations facilitating its dramatic growth globally—have enabled it to evade many of these 
constraints, rendering it a "more perfect commodity" for accumulation. Second, expansion of the market good of bottled water alters the prospects for the largely publicly provided good of tap water. Half of all bottled water sold in the United States today is filtered municipal tap water (Food and Water Watch 2010a), yet the bottled water industry contributes to the devalorization and deterioration of public drinking water systems in both the global North and South, both directly and indirectly (Parag and Roberts 2009). However, its rapid expansion has not gone unchallenged. In this article, we draw on interviews with participants in two U.S. cases of proposed spring water extraction from rural communities by the industry leader Nestlé Waters to illuminate the tensions between differing conceptions regarding the nature and ownership of water. As the case studies illustrate, the opposition generated by bottled water's extraction and consumption has raised the industry's costs and helped to alter its accumulation strategies. Nonetheless, given the large proportion of the public in both North and South that already relies on bottled water for at least part of its drinking water supply, we conclude that the continued growth of this commodity represents a tangible threat to the project of universal safe public drinking water provision, one likely more serious than that posed by the broader phenomenon of tap water privatization itself.

\section{Water: Privatization, Commodification, and Resistance}

\section{Theoretical Perspectives on Commodification}

In his foundational work The Great Transformation (1944), Karl Polanyi identified what he termed the "fictitious commodities" of land, labor and money as central to the destructive tendencies of an unregulated market economy. While genuine commodities are produced for sale in the market, 
Labor is only another name for a human activity which goes with life itself, which in its turn is not produced for sale but for entirely different reasons, nor can that activity be detached from the rest of life, be stored or mobilized; land is only another name for nature, which is not produced by man; actual money, finally, is merely a token of purchasing power ... None of them is produced for sale. The commodity description of labor, land, and money is entirely fictitious (1944: 72).

Polanyi wrote that $19^{\text {th }}$-century society had undergone a "double movement" in which "the extension of the market organization in respect to genuine commodities was accompanied by its restriction in respect to fictitious ones" (1944: 76), through increased state regulation of capital and the rise of labor movements and the welfare state. However, neoliberal globalization has since removed or weakened many of these safeguards, and stretched the fictitious commodities even further into new areas such as knowledge, body parts, life forms, and genes (Kloppenburg 2004; Laxer and Soron 2006). The commodification of water-an element of Polanyi's land-likewise offers a provocative modern case study of the perils of the commodity fiction.

Some scholars (e.g., Roberts 2008) describe the conversion of water and other public goods into marketable commodities as a form of primitive accumulation, drawing on Marx's (1867) analysis stressing the historical process by which capitalism has separated producers from the social means of subsistence and production (Glassman 2006). However, the geographer David Harvey (2003) has usefully extended Marx's framework to emphasize the variants of these dynamics occurring in the present day, coining the term "accumulation by dispossession." This phenomenon, Harvey argues, is a response by capital to a crisis of overaccumulation—_a condition where surpluses of capital...lie idle with no profitable outlets in sight" (2003: 149) — in which it must conquer new terrains in order to retain or return to profitability. "What accumulation by dispossession does," writes Harvey (2003: 149), “is to release a set of assets ... 
at very low (and in some instances zero) cost. Overaccumulated capital can seize hold of such assets and immediately turn them to profitable use."

At the heart of this phenomenon is the process of commodification - the incorporation of formerly public, common-pool, or otherwise non-market goods, resources, and services into the market. Harvey describes privatization as the "cutting edge" of accumulation by dispossession, stressing the role played by the World Bank, IMF, and WTO in imposing privatization of public goods, services, and property upon Southern debtor nations under structural adjustment regimes, through conditionalities attached to debt renegotiation (2003: 148).

Several scholars have applied Harvey's influential framework to water and extended it, analyzing both the broad process of commodification and specific instances of water privatization in various countries, as well as the opposition they have engendered (e.g., Ahlers 2010). "Nature itself has long resisted commodification," argues Swyngedouw (2005: 87), but in recent years, nature and its waters have become an increasingly vital component in the relentless quest of capital for new sources of accumulation ... a local/global choreography is forged that is predicated upon mobilizing local $\mathrm{H}_{2} \mathrm{O}$, turning it into money, and inserting this within transnational flows of circulating capital.

Thus, the privatization of drinking water can be understood as one facet of a much broader, ongoing process of commodification of nature, linked to the strategies of global capital firms to ensure continued accumulation.

\section{Overcoming Barriers to Accumulation in Agrifood Systems}

These core themes are also central to debates within the literature on the political economy of agrifood systems regarding the nature of enclosures in the realm of agricultural production. This extensive literature traces its origins at least to Mann and Dickinson's (1978) examination of the persistence of family agriculture in highly industrialized economies, which they attribute to the incompatibility of some aspects of commodity production with the 
requirements of capital accumulation. More recently, this scholarship has raised the question of which factors have enabled capital to overcome structural obstacles to accumulation under neoliberalism, centering in particular on the role played by genetic engineering and seed biotechnology. Kloppenburg (2004) and others have persuasively argued that seeds, because of their unique structural characteristics - they are self-reproducing and can be saved—-have offered a particularly large stumbling block to capital accumulation" (Mascarenhas and Busch 2006: 125). Their dual structural character, as both the means of production and as grain, "is antagonistic to the complete assimilation of seed (as opposed to grain) under the commodity form” (Kloppenburg 2010: 370). However, genetic engineering (GE) has managed to overcome that barrier to enclosure in several major crops. According to Pechlaner and Otero (2010: 185), GE represents "the key technology driving capital accumulation in the neoliberal food regime." Of course, while this technology is transformative, it has ultimately only succeeded due to the broader political, institutional, and even discursive frameworks within which it is situated (e.g., Kinchy, Kleinman, and Autry 2008). This context includes intellectual property regimes in international trade and investment agreements that offer legal recognition of patents on life and seed licenses, dramatic industry consolidation, and a deregulatory agenda that in the United States ironically prohibits the labeling of foods containing GE ingredients. These transformations in the in the agrifood realm have also generated a diverse and growing set of counter-movements, which aim to resist and/or reverse such enclosures.

In this article, we draw parallels between these phenomena of enclosure and dispossession in the agrifood arena and similar dynamics occurring with regard to water. We focus in particular on the specific ways in which drinking water has posed obstacles to accumulation, and how the technological development of bottled water and its transformation 
into a global commodity has managed to surmount these hurdles. We will now briefly review some of the key issues regarding the privatization of tap water, before turning our focus to bottled water.

\section{Privatizing the Tap}

An estimated 40 percent of the world's citizens do not have reliable access to potable water supplies (Barlow 2007; Shiva 2008). In many cities of the global South, only upperincome residents are served by the municipal piped water networks taken for granted in much of the North. Middle- and lower-income neighborhoods often must rely on a mix of informal sources, including water vendors and locally bottled water, for which they pay many times more than their often wealthier neighbors served by tap water (Bakker 2010). Due in part to this growing crisis of both quantity and quality, water has been framed as the figurative "blue gold" of the $21^{\text {st }}$ century (Barlow and Clarke 2002; Dilworth 2007) and increasingly represents a profitable commodity to be sold to consumers at market rates.

A global water industry has for over 20 years been focused on privatizing the provision of municipal drinking water supplies in the global South, as well as the North (Snitow, Kaufman, and Fox 2007). Two multinational corporations, French-based Suez and Veolia, presently control 70 percent of a rapidly growing drinking water market worth over $\$ 400$ billion (Barlow 2007). In 2011, private water firms supplied over 900 million people, or 13 percent of the global population, up from 50 million in 1990 (Pinsent Masons 2011).

The privatization of public water services in the global South was largely imposed, especially during the 1990s, through World Bank and IMF loan conditionalities and structural adjustment programs requiring states to open up public utilities for sale, lease, or concession (Goldman 2005; Conca 2008). Yet the result of two decades of private sector involvement, 
many observers concur, has been a failure by the market to meet the stated goal of "water for all" in the global South (Castro 2008; Kessides 2005; Prasad 2006; Swyngedouw 2005). Even the World Bank has since acknowledged that privatization has generated social discontent but neither sufficient profits nor adequate numbers of new water connections (World Bank 2005).

Public resistance to tap water privatization has often been quite strong. The April 2000 "water war" in Cochabamba, Bolivia, which some observers have characterized as an early victory against the neoliberal model, is the subject of particular scholarly interest ${ }^{2}$ (e.g., Spronk and Webber 2007), but major anti-privatization protests have also erupted in Argentina, Uruguay, Tanzania, and South Africa (Bond 2005; Castro 2008; Vidal 2005). A clear deprivatization trend has emerged, as both governments and firms terminate concession contracts (Vidal 2006). Currently, argues Bakker (2010), there is a "stalemate" in water privatization, with transnational firms retreating from long-term concessions in urban areas, but remaining involved in the management of water and sewerage systems (Barlow 2007; Packaging Digest 2010).

The reasons for this stalemate are particularly germane to the contrast with bottled water we draw in the following sections. First, providing universal tap water service is not sufficiently conducive to accumulation, due in part to the need for extensive sunk costs in maintaining and expanding water treatment and delivery networks (Loftus 2009). Second, tap water has proved insufficiently price elastic to allow firms to raise water rates high enough to deliver the profit levels they seek; doing so often leads to mass disconnections for nonpayment and/or large-scale social conflict (Swyngedouw 2005). Third, while anti-privatization protests have only occurred

\footnotetext{
${ }^{2}$ After a World Bank-imposed, single-bidder concession to a local subsidiary of the U.S.-based Bechtel Corporation led to large water rate hikes, residents of Cochabamba, Bolivia responded with mass protests that eventually forced company officials to flee the country and cancel the contract (Driessen 2008; Spronk and Webber 2007).
} 
in a minority of cases, they have played a key role in the cancellation of a number of privatization contracts (Bakker 2010; Lobina and Hall 2007).

Bakker argues that water's geography, its sociocultural qualities, and its nature as a flow resource, render it an "uncooperative commodity" (2005: 559). Likewise, Snitow and Kaufman (2007: 197) write that because water is "heavy, slippery, and expensive to transport, it resists being made into a commodity." That is, it does not cooperate sufficiently well with capital to ensure sustained high levels of accumulation. However, this useful framing encounters at least two significant limitations. First, it at least partly contradicts the arguments of Harvey and others that water privatization is a prime example of accumulation by dispossession, a disjuncture we revisit in the discussion section later in the article. Second, it does not capture the ways that distinct forms of water turn out to pose differential barriers to accumulation, as we discuss below.

The privatization of tap water in the United States illustrates many of the same contradictions that apply in the global South. Although 86 percent of the U.S. population is served by publicly owned water utilities, many fiscally-strained local governments in the 1990s turned to private firms as a way to maintain aging water delivery and sewerage systems, (Food and Water Watch 2008; Snitow, Kaufman, and Fox 2007). However, grassroots social movements have succeeded in reversing private concessions in several large cities, including New Orleans; Indianapolis; Atlanta; Stockton, California; and Laredo, Texas (Barlow 2007). Privatization failures in these and several other cities led to a trend of remunicipalization over the past decade, in which contracts were canceled either by firms or local governments, and management reverted to the public sector (Esterl 2006; Food and Water Watch 2008; Snitow, Kaufman, and Fox 2007). However, the current recession has caused a renewed surge of system 
privatizations and sales (Food and Water Watch 2010b). Estimates for the 20-year cost of maintaining public drinking water and sewerage systems in the United States run as high as \$1 trillion, yet public funding has fallen far short of the need and continues to decline (Szasz 2007: 200). These infrastructure backlogs have led to occasional high-profile instances of unsafe water, contributing to a growing public distrust of tap water quality (Parag and Roberts 2009). This phenomenon is closely linked to the growth of bottled water.

\section{Bottled Water}

The dramatic surge in bottled water consumption has spawned a global industry. The international bottled water market - expected to surpass \$65 billion in 2012 (Boreal Water News 2010) — is dominated by four food and beverage giants: Nestlé, Danone, Coca-Cola, and PepsiCola. These firms are developing high-capacity bottling plants to extract groundwater worldwide (Barlow 2007; Packaging Digest 2010; Rodwan 2011). The water itself can be global as well. According to Barlow, almost 25 percent of all bottled water crosses national borders, with firms often taking "water from poor communities in the global South to sell to rich markets in the global North" (2007: 84). The large majority of bottled water extracted in Southern nations, however, is consumed locally. Increasingly, the transnational bottled water firms are buying up local companies and targeting middle (and upper) class consumers, while the remaining local vendors, often unregulated, supply many poorer residents with water of dubious provenance and quality at far higher prices than their wealthier neighbors pay for tap water (Girard 2009).

In the United States, the bottled water industry has consolidated rapidly as demand has skyrocketed. Nestlé Waters is the undisputed industry leader with a 35 percent share of the $\$ 15$ 
billion annual market, followed by Coca-Cola ${ }^{3}$ (Dasani) and Pepsi (Aquafina), each with 11 percent (Beverage Marketing Corporation 2010). A substantial portion of the U.S. population now consumes this commodity. A 2003 Gallup poll showed that 74 percent of Americans drink bottled water, with 20 percent consuming it "exclusively" (Szasz 2007: 133). Prices for bottled water are dramatically higher than for tap water, ranging from 240 to 10,000 times more per unit volume (Natural Resources Defense Council 1999). Half of the bottled water sold in the United States is simply municipal tap water that has been treated and/or filtered (up from one-third in 2000), with the remainder extracted from natural springs or groundwater (Food and Water Watch 2010a). Coke's Dasani and Pepsi’s Aquafina are drawn entirely from public tap water systems, while Nestlé sells several brands from both municipal and spring sources.

The environmental impact of bottled water is also substantial. Its production and distribution consume between 1,000 and 2,000 times more energy per unit volume than local tap water, and U.S. bottled water consumption requires the energy equivalent of between 32 and 54 million barrels of oil per year (Gleick and Cooley 2009). Bottled water's negative externalities also include the impact of the extraction itself on springs and rivers, local ecosystems, agriculture, wells, and other water users.

Industry advertising campaigns subtly or overtly denigrating tap water have played a key role in altering public perceptions and behavior. The disappearance of water fountains in public places $^{4}$ and the desire to consume "on the go" have also hastened the move toward bottles (Girard and Shaker 2008; Szasz 2007). The industry also promotes its product by associating it with exercise and a healthy lifestyle, contributing to a long-term shift away from the

\footnotetext{
${ }^{3}$ Danone Group's U.S. holdings were acquired by Coca-Cola in 2005, but the firm remains a major player elsewhere (Clarke 2007).

${ }^{4}$ Girard and Shaker (2008) attribute the decline and deterioration of public water fountains in Canada to a combination of "profit, underfunding, and ideology."
} 
consumption of soft drinks, but also away from tap water (Gleick 2010). The overall result has been the normalization of bottled water across society in a remarkably short period of time.

Given the social and cultural shifts tied to bottled water's growth in the past three decades, the paucity of scholarly attention to this phenomenon among sociologists is striking. Nonetheless, a few substantive contributions are worth noting. Sociologist Andrew Szasz describes bottled water as the prime example of a phenomenon he terms "inverted quarantine": the pursuit of individual solutions to perceived environmental risk based on the consumption of safer products. Szasz argues that the inverted quarantine response diminishes the intensity of public demands for policy change because it produces a "false sense of security, undercutting political support for reform" (2007: 202). The growth of bottled water not only feeds a generalized weakening of public policy responses, but also contributes to additional decline in public water infrastructure. Parag and Roberts (2009) contend that this decline imperils tap water quality and further accelerates the shift toward the private solution of bottled water, at least for those able to afford it. John Vail, in a broader discussion of the effects of commodification upon society, argues that "when people opt for private services,"

they often prove less willing to fund public goods, the quality of public services subsequently worsens, thereby weakening the very rationale for these goods and creating a vicious spiral of decline that grievously corrodes the public's trust of government services and damages the very possibility of cultivating a shared sense of community upon which a democratic citizenship is founded (2010:326).

Thus the societal implications of this commodity extend beyond water to the broader questions of the market's steady incursion into the public sphere and its implications for democracy.

\section{Movements Against Bottled Water}

The dramatic growth of this commodity has not gone unchallenged. An increasingly effective social movement against bottled water has developed in the past decade, particularly in 
North America and Europe. This movement has taken two principal forms: on one hand, campaigns to "take back the tap" by persuading consumers to eschew bottled water and pressuring public institutions and local governments to stop buying it; and on the other hand, local opposition to specific instances of spring water extraction by the industry. "These efforts," writes Gleick (2010: 145), "are squeezing the industry at two ends: putting pressure on demand, and drying up supply."

A number of cities ${ }^{5}$ have recently passed laws prohibiting municipal purchases of bottled water, sometimes linked with commitments to reinvest in public infrastructure such as drinking fountains (Velasquez-Manoff 2009). These cities and others have also launched advertising and PR campaigns to revalorize tap water, promoting the quality of public water supplies and distributing refillable bottles to residents (Gentile 2008). A number of university campuses have banned sales of bottled water in the wake of student campaigns, and some restaurateurs have ceased offering it to customers. Many of these efforts have received support from a network of national and international NGOs, most prominent among them Corporate Accountability International, Food and Water Watch, and the Polaris Institute. Increased media coverage of the negative environmental effects of bottled water has also contributed to shifting public sentiment.

The other arena involves contestation over the extraction of spring water. In the United States, Nestlé's efforts to meet increasing demand, by siting new high-capacity wells and bottling plants and expanding others, have been the focus of protracted grassroots opposition (Barlow 2007; Clarke 2007; Velasquez-Manoff 2009). In these areas, residents and environmental groups have raised concerns about issues including the depletion of local groundwater supplies; harm to local fisheries; and the minimal compensation paid to local

5 These cities include San Francisco, New York, St. Louis, Vancouver, Toronto, and Liverpool. 
communities or governments relative to the high water volumes extracted (Snitow, Kaufman, and Fox 2007). In many of these cases, Nestlé has acquired legal rights or title to the water and/or land and actively courted local officials, often prior to making its plans public (Hall 2009; Snitow, Kaufman, and Fox 2007). Bottled water extraction has also been a flash point for local activism in the global South, with major conflicts erupting in Pakistan (Nestlé), Indonesia (Danone and Coca-Cola), India (Coca-Cola), and Mexico (Coca-Cola) (Barlow 2007; Raman 2010).

The net effect of these various movements has been to contribute to shifts both in public attitudes toward bottled water and in the fortunes of the industry. In 2008 and 2009, the global market for bottled water shrank for the first time ever, a reversal due in part to the global recession but also to push-back from opposition movements (Packaging Digest 2010).

The bottled water industry has responded to the growing controversy in several ways. It has waged an aggressive public relations campaign to oppose "take back the tap" efforts (Gleick 2010). Nestlé has changed its commercial strategies, increasingly moving away from outright acquisition of land and water rights toward extracting spring water as the customer of local public water utilities, but with long-term contractual access rights - a strategy employed in the case studies we profile in the following section. The firm is also shifting from establishing new spring water extraction sites toward the (so far) less conflictive practice of drawing from municipal sources, as its main competitors Coke and Pepsi do exclusively (Food and Water Watch 2010a). While spring water by federal law must be bottled with little or no alteration and is marketed for its allegedly "pristine" qualities, bottled tap water is typically filtered and supplemented with minerals, and often marketed with reference to the "hypertechnological intervention" involved (Szasz 2007: 123-24). The rapid growth of Nestlé's municipally-sourced 
Pure Life brand indicates that many consumers do not find drinking filtered tap water objectionable or problematic, yet it also raises intriguing questions. What are the implications of a major increase in extraction from public tap systems by the very actors who are simultaneously waging an all-out campaign to persuade consumers that tap water is unsafe to drink?

Returning to the broader issues raised in this section, the extraction of water by beverage firms — depending on the property rights regime involved — can be conceptualized as ranging from privatization to "merely" commodification. Yet in all of the contexts mentioned above, we argue, it does constitute accumulation by dispossession. Moreover, bottled water merits particular attention because it is not hindered by many of the obligations and tethers for capital that have limited the commodification of tap water globally. Nevertheless, the paucity of empirical case study research examining how bottled water commodification unfolds and is contested in specific locations - particularly within the United States - is noteworthy. Existing scholarly analyses have either placed bottled water as a minor coda to discussions of tap water privatization or conflated the two processes, overlooking the fundamental distinctions we have outlined above. In the following section, we examine two instances of conflict over proposed bottled water extraction by the world's largest agrifood firm, Nestlé. These cases serve to illuminate our principal contention that bottled water has posed lower barriers to commodification than municipal supplies, and they illustrate capital's shifting accumulation strategies regarding both forms of water.

\section{Contesting Bottled Water Extraction in the North: Local Conflicts, Global Implications}

In this section we examine two case studies of contestation over bottled water extraction: McCloud, California, situated at the foot of Mount Shasta in the state's far north, and Cascade Locks, Oregon, located in the Columbia River Gorge 40 miles east of Portland. Both are 
economically distressed former mill towns that have recently been riven by proposals by Nestlé Waters to tap local springs and establish high-capacity water bottling plants for its Arrowhead spring water brand. Nestlé Waters is the largest and most profitable bottled water firm and the biggest supplier of spring water, with North American profits of $\$ 4.2$ billion in 2009. It owns 15 water brands and operates 50 spring water extraction sites in 15 U.S. states (Ball 2010; Correll 2009). As two of the most recent proposals by Nestlé to establish new bottling facilities ${ }^{6}$, these cases are broadly representative of the conflicts that have arisen over bottled water extraction elsewhere in the United States; they illustrate major trends within the industry as well as the tactical and strategic approaches of the organizations opposing it (Clarke 2007; Snitow, Kaufman, and Fox 2007.

\section{McCloud, California}

An unincorporated hamlet of just over 1,200 residents, McCloud was long a company town owned by the local lumber mill. The timber industry faded in the 1990s, and the mill closed entirely in 2002, pushing the town's unemployment rate to over 20 percent. In September 2003, officials of the McCloud Community Services District (MCSD) voted to approve a contract with Nestlé that had been negotiated in secret, with no public input. The contract would have allowed the firm to build the nation's largest water bottling plant, giving it access to 520 million gallons of water from local springs annually for 99 years as a customer of the Services District. Although Nestlé would have paid the district only $\$ 0.00008$ per gallon (one cent for each 123 gallons of water), far below industry norms, the contract would have generated $\$ 350,000$ annually for MCSD, whose total revenues were close to $\$ 1$ million (Conlin 2008b).

\footnotetext{
${ }^{6}$ In 2009, Colorado officials approved a controversial proposal by Nestlé to build a facility in
} Chaffee County to extract 65 million gallons of groundwater annually (Correll 2009). 
After several legal challenges, Nestlé was obligated to prepare an Environmental Impact Report required by California law, which slowed approval significantly. In the meantime, local opposition became organized. Several local residents formed the McCloud Watershed Council (MWC), which worked in coalition with angler groups Trout Unlimited and California Trout, and later collaborated separately with Food and Water Watch.

When Nestlé announced in 2008 that it would dramatically reduce the size of the proposed plant, Business Week described the case as a "cautionary tale for any company. [Formerly], multinationals could arrive in economically depressed communities and pretty much have their way. But in the age of hyper-connectedness, residents in McCloud were able to turn their issue into an international sensation. Now Nestlé has capitulated" (Conlin 2008a). Then in September 2009, Nestlé rescinded its McCloud proposal entirely, saying it no longer had a need for the site. Only a few months earlier, the firm had reached agreement with city officials in Sacramento, California, to build a large plant there to bottle municipal water, which began operation in 2010 .

\section{Cascade Locks, Oregon}

As Nestlé was beginning its withdrawal from McCloud in 2008, the firm announced a proposal for another bottling plant in Cascade Locks, Oregon, a village of 1,100 located on Interstate 84 along the Columbia River. At less than 200 million gallons per year, this plant would be considerably smaller than that proposed for McCloud, although other aspects of the deal were similar, such as giving Nestlé a long-term (50-year) guarantee to spring flows. Cascade Locks officials are eagerly supporting a complex water-swap proposal that would give Nestlé access to spring water currently used by a state fish hatchery, in exchange for providing higher volumes of city-owned well water to the hatchery. According to company and city 
officials, Nestlé would pay one-fifth of a cent per gallon as a customer of the municipal water utility, generating about $\$ 350,000$ annually for Cascade Locks, plus another $\$ 150,000$ in taxesa sum roughly triple the town's total current property tax revenues. The company promises that the plant will generate 48 full-time, living-wage jobs in this economically depressed community, a contention challenged by opponents (Ball 2010).

In contrast to McCloud, little public opposition has emerged within Cascade Locks to the proposal. However, a coalition of NGOs was formed to challenge Nestlé's plans at the state level, including the Sierra Club and Food and Water Watch. While the state Department of Fish and Wildlife supports the proposal, opponents are mobilizing public opposition in an effort to defeat the water swap. As of this writing, no decision has been taken, and Nestlé-perhaps learning from its lessons in McCloud — has neither committed in writing to build the plant nor proffered a specific contract.

\section{Data and Research Methods}

The data on which the analysis in this section is based are principally drawn from ethnographic field research. Between March 2010 and June 2011, the authors conducted semistructured interviews with a range of participants involved in the controversies over bottled water in McCloud and Cascade Locks. These included community residents, local and state officials, staff and volunteers with local, regional, and national NGOs and advocacy groups, and a Nestlé representative involved in negotiating both proposed bottling plants. We conducted a total of 29 interviews with 28 participants (one was interviewed twice); two interviews were conducted by telephone and 27 in person. Of these respondents, four represented organizations involved in both case study sites; eight were community residents or representatives of organizations involved in the McCloud case; and 16 were community residents, elected officials, or 
Table 1: Key Organizations and Respondents in Bottled Water Case Studies

\begin{tabular}{|l|l|l|l|l|l|}
\hline $\begin{array}{l}\text { Organization } \\
\text { or Group of } \\
\text { Respondents }\end{array}$ & $\begin{array}{l}\text { Headquarters/ } \\
\text { Location }\end{array}$ & $\begin{array}{l}\text { Scope of } \\
\text { Operations }\end{array}$ & $\begin{array}{l}\text { Type of } \\
\text { Organization }\end{array}$ & $\begin{array}{l}\text { Case } \\
\text { Study } \\
\text { Site(s) }\end{array}$ & $\begin{array}{l}\text { Number of } \\
\text { Respondents }\end{array}$ \\
\hline $\begin{array}{l}\text { Nestlé Waters } \\
\text { North America } \\
\text { (Nestlé S.A.) }\end{array}$ & $\begin{array}{l}\text { Stamford, CT } \\
\text { (Vevey, } \\
\text { Switzerland) }\end{array}$ & $\begin{array}{l}\text { U.S., Canada } \\
\text { (Global) }\end{array}$ & $\begin{array}{l}\text { For-profit } \\
\text { corporation }\end{array}$ & $\begin{array}{l}\text { McCloud, } \\
\text { Cascade } \\
\text { Locks, }\end{array}$ & 1 \\
\hline $\begin{array}{l}\text { Food and } \\
\text { Water Watch }\end{array}$ & $\begin{array}{l}\text { Washington, } \\
\text { DC }\end{array}$ & International & Nonprofit & $\begin{array}{l}\text { McCloud, } \\
\text { Cascade } \\
\text { Locks, }\end{array}$ & 2 \\
\hline $\begin{array}{l}\text { California } \\
\text { Trout }\end{array}$ & San Francisco & Statewide (CA) & Nonprofit & McCloud & 1 \\
\hline $\begin{array}{l}\text { McCloud } \\
\text { Watershed } \\
\text { Coalition }\end{array}$ & McCloud, CA & Local & $\begin{array}{l}\text { Non-profit, } \\
\text { grassroots }\end{array}$ & McCloud & 2 \\
\hline Sierra Club & $\begin{array}{l}\text { Washington, } \\
\text { DC }\end{array}$ & $\begin{array}{l}\text { National, } \\
\text { Regional }\end{array}$ & Nonprofit & $\begin{array}{l}\text { McCloud, } \\
\text { Cascade } \\
\text { Locks }\end{array}$ & 1 \\
\hline $\begin{array}{l}\text { Alliance for } \\
\text { Democracy }\end{array}$ & Waltham, MA & National, Local & Nonprofit & $\begin{array}{l}\text { Cascade } \\
\text { Locks }\end{array}$ & 1 \\
\hline $\begin{array}{l}\text { Community } \\
\text { Residents } \\
\text { unaffiliated) }\end{array}$ & --- & ---- & $\begin{array}{l}\text { Cascade } \\
\text { Locks }\end{array}$ & 12 \\
\hline $\begin{array}{l}\text { Community } \\
\text { Residents } \\
\text { unaffiliated) }\end{array}$ & --- & ---- & $\begin{array}{l}\text { Cascade } \\
\text { Locks }\end{array}$ & 3 \\
\hline Public officials & --- & --- & McCloud & 1 \\
\hline TOTAL & --- & -- & $\mathbf{2 8}$ & 4 \\
\hline
\end{tabular}


organizational representatives involved in the Cascade Locks case. Table 1 depicts the distribution of interview respondents by organization and by community. The interviews lasted between 45 minutes and two hours and were audio recorded. We initially assembled a core list of respondents from a small number of key informants; once interviews had begun we expanded the list through snowball sampling. Our aim was to construct a sample broadly representative of the range of participants and opinions involved in each site. While we only quote from a subset of the interviews in this article with the aim of representing the key actors and major issues, the remainder of the interview data strongly informs the broader analysis. These interviews were supplemented with observation at public meetings and other events.

\section{Local Contestation: Key Dimensions}

In our interviews, several common foci emerged which help to illuminate the broader conceptual and theoretical issues involved in the commodification of water. These recurring topics include: 1) divergent local framings of water's significance; 2) perceptions of ownership and control (or the lack thereof) over water; 3) the relationship between local instances of water extraction and broader issues of privatization; and 4) tactical or strategic choices made by opponents, and assessments of the outcomes and future prospects of these struggles. Each of these themes illuminates distinct facets of the earlier theoretical discussion, as we describe below.

First, residents of McCloud and Cascade Locks and Nestlé staff vocalized a range of distinct understandings of the nature of local water, its relation to economic well-being, and the appropriateness of commodifying it. These concerns speak to the question of water's uniqueness and whether or not its transfer from the public sphere to the market constitutes accumulation by 
dispossession. "This is the only thing the Service District has to sell," said a McCloud resident who strongly supported Nestlé's proposal:

We have water - pure, simply, end of the story, water. That's all we have to sell, other than what you get from me every month [in taxes]. And you have no sales tax [receipts] here, because we're not incorporated. And so we have water...So we thought, "gee, who could complain about a clean industry, a water bottling plant?"

Other residents of both communities similarly expressed bafflement over their neighbors' and NGOs' opposition to the siting of what they perceived as a job-creating industry like any other.

The company's rhetorical approach echoes this framing of water as merely another commodity. "It's unfortunate that these organizations are taking a stance of banning bottled water," argued the Nestlé representative active in both the McCloud and Cascade Locks proposals:

Our company has taken the position that people should drink more water, whether it's bottled or tap water. We think the consumer should have a choice out in the marketplace when they're looking for a beverage. We are not in competition with tap water... There's an epidemic of diabetes and obesity in this country and if bottled water disappeared today, people would not be turning to tap water.

On the other hand, a staff member of California Trout who was actively involved in the antiNestlé coalition focused on the polarized politics that have often pitted greens against resourcedependent communities:

This is a town that was booming in the timber industry days, and then from their perspective, environmentalists said "oh we're going to run out of trees." And the timber industry collapsed... So now, we're never going to run out of water, there's glaciers on the mountain for heaven's sake; water just bursts up out of the ground all over the place. But environmentalists came in and said, "Oh we're going to run out of water"... And that's how they look at it; the environmentalists are trying to take their water. Why would they give it to the environmentalists for free when they could sell it to Nestlé for nothing?

Second, many residents and activists also spoke passionately about the issue of local control over water resources, and the perceived threats to such control. These concerns speak to the question of the nature of the enclosure entailed by bottling local springs. A resident of 
Cascade Locks opposed to Nestlé described the central issue as one of public ownership of water (literal state ownership, in this case) being compromised by negotiations between Nestlé, the city, and one state agency:

When I found out that they wanted to trade spring water with the Department of Fisheries over here, I thought, "why?" You know, the water belongs to the state- to all of the people - not just the fisheries, not just to Nestlé or the city. It's all of ours and they have no business selling it for nothing so that this company can make a huge profit on it.

This appeal to a notion of water as part of a commons echoes themes used by social movements elsewhere opposed to privatization of water and other natural resources (Harvey 2003). A representative of the Oregon Department of Fish and Wildlife, in contrast, argued that the arrangement poses no threat to public ownership: "We're not going to give up our water rights, so that leaves us in control. If the only way forward would have been for us to give some of our water rights away, I highly doubt we would have continued to talk, [but] we will remain the owner of that water resource up there. And we'll protect it."

In McCloud, concern about the potential loss of local control over water was a powerful theme for opposition groups. According to the town resident who founded the McCloud Watershed Council and led the anti-Nestlé effort,

The main reason that the people who switched from pro-Nestlé to anti-Nestlé [did so] was the fact that in the contract, it stated that if we were to go into drought... McCloud would have to dig the wells, we would have to drink the well water, and Nestlé would get our pure spring water.

Nestlé's purchase of the bottling plant site in McCloud did not come with rights to access the springs, so the firm proposed a long-term contract to purchase the water from MCSD as a customer. Another McCloud resident addressed how this strategy relates to questions of control:

A lot of [water companies] like to own the spring and the rights and everything, because they can do whatever they want. [But] Nestlé in a lot of places prefers to be a customer, because then you can't really directly blame them for the overpumping. 
A third issue - central to the relevance of the frame of accumulation by dispossession to this context - is whether bottled water extraction is understood as constituting privatization of a local water resource. "Sometimes the issue of privatization of water comes up," said the Mayor of Cascade Locks. "Well, it's not the case. We are essentially selling them a water resource. They will become an industrial customer just like any other, whether it's them selling me the water that comes out of my tap, or any other large user of water." This description, however, elides the question of the long-term contractual rights Nestlé insisted upon in both communities. When asked whether bottled water extraction equaled privatization, a member of the McCloud Watershed Council answered unequivocally, "Yes, because they were taking from our water supply and they were claiming hold over our water supply. Yes. That is water privatization. That's taking local control of a water resource out of local hands."

A final theme regards the tactical and strategic choices made by opponents, and the future prospects for Nestlé's extraction of bottled water. In their claimsmaking, the various actors challenging the two bottling facilities drew upon (and reinforced) shared understandings of water's scarcity to argue for the need to erect higher obstacles to accumulation through legal, regulatory, and corporate campaigning strategies, thus raising Nestlé's costs and changing the firm's calculus. At the same time, many of these arguments ironically ended up conceding the market frame. When Nestlé withdrew its McCloud proposal in 2009, local opponents and the NGO coalition supporting them had held off the company for six years. The California Trout staff member discussed the question of which themes had found the greatest resonance among residents of McCloud:

We framed it with two things. That really we are sort of interwoven, that water is more valuable than this [Nestlé plant]. And that ...you guys are getting screwed. You're getting paid nothing for this water. Nestlé is going to make billions of dollars ... and you got treated like a third world nation by them. And you deserve better than that. If selling 
water is a good idea, then think about what you just did-you just sold the farm for almost nothing.

In analyzing the outcome, several local residents said they had prevailed due of a mix of local opposition, legal challenges, and public relations harm to Nestlé from unfavorable media coverage. However, the California Trout staff member attributed the victory to a different set of factors:

In my most honest moments I think we ran out the clock for them. We had enough hook with CEQA ${ }^{7}$ to hold them off while the whole thing unraveled. And it unraveled for Nestlé on its own - bottled water, the economy, all those other things. They came because they had a business model that worked, and they left because their business model no longer worked, and I don't have any illusions about me convincing Nestlé that McCloud was not the place.

Many of the NGO representatives claim that in announcing its plans for Cascade Locks, Nestlé had transferred the McCloud proposal to Oregon, in hopes of finding a more favorable community and regulatory environment. "Their water sources in California are drying up," said the Oregon Food and Water Watch organizer, "and they just got kicked out of the Mt. Shasta area...they don't have a single water bottling operation in the Northwest and they know that this is a wet region and they want to get a foothold." Nevertheless, with Nestlé both continuing to pursue the Cascade Locks spring water site and expanding its municipal water bottling as of this writing, it remains unclear whether local opposition has been successful in significantly raising barriers to future instances of commodification or obliging the firm to fundamentally reassess its strategies. We now turn to discussing the implications of these local conflicts for our broader analysis of the dynamics of commodification.

\footnotetext{
${ }^{7}$ CEQA is the California Environmental Quality Act, which required an environmental impact assessment of Nestlé's proposal.
} 


\section{Discussion: A More Perfect Commodity}

As the previous section indicates, bottled water raises intriguing issues regarding the dynamics of privatization and accumulation. The two cases of proposed water extraction profiled above — if approved—would unambiguously constitute commodification, as Nestlé would tap publicly-owned local springs to sell bottled water to distant markets. They would also represent clear instances of accumulation by dispossession, since they would alter public water rights (community ownership in the case of McCloud, or state ownership in Cascade Locks) through contractual obligations that-while technically maintaining Nestlé's status as a utility customer-would nonetheless give the corporation priority rights to spring water flows over local needs. On the other hand, since the company would acquire legal title to neither land nor water, these examples do not constitute the privatization of water, the opinions of some local residents notwithstanding. This suggests the need for additional interrogation of the boundary between commodification and privatization, both in the case of water and more generally.

These case studies also illustrate the two key contentions made in this article, concerning both the challenge bottled water poses to existing theoretical framings regarding the commodification of water, and the relationship between this market commodity and the (largely) publicly provided good of tap water. Bottled water, regardless of its origin, does not present many of the barriers to capital accumulation posed by tap water networks, rendering it — in contrast with Bakker's (2005) framing of water as an "uncooperative commodity" — a more mobile and more profitable commodity. This, in turn, presents a serious challenge to the prospects of public drinking water. Several examples illustrate these linked arguments.

First, bottled water requires virtually none of the sunk fixed infrastructure costs and 
obligations of municipal water systems. Private management contracts for municipal networks typically require firms to make substantial investments to maintain water quality and the physical water treatment and distribution network, as well as meet increasing public health and environmental standards, hire and train staff, manage billing, and handle other imponderables that can reduce profit margins or make returns unpredictable. In contrast, bottled water firms have a very limited set of investments (particularly if they use municipal water sources): they frequently bottle water at the same plants as other beverages and distribute them through existing networks. An industry newsletter underscores this point: "Entry barriers are low, and decreasing by the day" (Boreal Water News 2010). These factors enhance profitability. While the protests in Bolivia and other nations were sparked when private firms raised tap water rates enough to achieve a contractually guaranteed return of 15 to 17 percent (Bond 2005; Castro 2007; Spronk and Webber 2007), profit margins for bottled water are higher, typically 25 to 35 percent and sometimes more for large bottlers (Natural Resources Defense Council 1999; Gleick et al. 2007). Second, bottled water defies, at least partially, the locality of water. Bakker asserts that because of its nature as a flow resource, "water is used and disposed of locally," typically close to the point of extraction (2010:200). However - much as the technological package of genetically engineered seeds removes a crucial obstacle to commodification of the food supplythe plastic integument of bottled water enables it to escape these fundamental constraints. Over one-quarter of all bottled water crosses national boundaries, making it truly a global commodity (Barlow 2007: 84), and much more travels long distances domestically, beyond local watersheds.

Third, bottled water is characterized by far more price elasticity than tap water. This is true in affluent nations, where bottled water sales are positively correlated with income and families spend hundreds of dollars per year on it (Gleick 2010), but it also pertains to places in 
the global South where safe public water supplies are lacking. While many of the effective popular protests against tap water privatization in the South were triggered by rate increases of 20 to 30 percent, the (often poorer) residents of the same countries not served by the municipal piped water system already typically pay many times those rates for water from local vendors, much of it bottled (Bakker 2010; Driessen 2008). The inability of the public sector to provide safe tap water to well over a billion people in the global South—often reinforced through debt conditionality—has facilitated the growth of the bottled water market, further exacerbating social inequality. Yet since water is essential for life, people faced with a lack of other options will often pay what the market demands. Where bottled water is the best or only option, its price elasticity—and the resulting profits—can be quite high indeed (Girard 2009).

Fourth, by acting to further public disinvestment and increase public distrust in tap water, bottled water literally builds its own market. According to Gleick (2010: 176), "the bottled water industry is successfully capitalizing on, and profiting from, the decay of our comprehensive safe drinking water systems, or, in the poorer countries of the world, their complete absence." Similarly, in the agrifood realm, genetic drift of patent-protected germplasm advances commodification by contaminating local crop varieties and undermining the longstanding efforts of seed savers, family and organic farmers, and public university plant breeders.

Finally, while the extraction of spring water for bottling is clearly an instance of primitive accumulation, the bottling of already-treated municipal tap water (altered merely with further filtration and mineral additives) represents a strange paradox. It constitutes a particularly extreme example of accumulation by dispossession, a process which Harvey (2003: 148) describes as involving "cannibalistic, as well as predatory, practices." By piggybacking on public water systems in this manner, bottled water parasitizes the public investment in clean tap 
water by serving up the very same substance for hundreds of times the cost, while the industry simultaneously "actively delegitimizes public water" (Parag and Roberts 2009: 633). The bottled water industry's expansion also serves to render those tap water sources-unless subjected to its own "hypertechnological intervention"—-ess dependable, less available, and less fit to drink (Szasz 2007). This is a neat trick, but one with quite serious implications for society and democracy.

These examples illustrate that compared with municipal water supply systems, bottled water constitutes a "more perfect commodity" for capital accumulation. ${ }^{8}$ One manifestation of this contrast is the rapid expansion of the bottled water industry globally (Rodwan 2011), as opposed to the far more problematic growth in private management of municipal tap water systems, characterized by high rates of failed privatizations and a trend of remunicipalization in both South and North (Bakker 2010; Bond 2005; Dilworth 2007; Esterl 2006).

\section{Concluding Observations}

As Harvey (2003) observes, the process of accumulation by dispossession is continuous, with capital constantly seeking new terrains into which to expand. We have contended here that some forms of the commodification of nature are more amenable to capital accumulation than others, and that both technological and political-economic developments are key to the transformations that enable such shifts. The case of bottled water clearly illustrates these key contentions. Bottled water currently represents the cutting edge of water commodification, and

\footnotetext{
${ }^{8}$ Other authors have engaged the notion of perfection with regard to commodities in the agrifood realm. DuPuis' (2002) exploration of the rise of consumption of cow's milk in the U.S. centers on milk's relatively recent social construction as the "perfect food" and a natural part of human diets.
} 
its extraction and manufacture involve processes of accumulation by dispossession that are more extreme, far-reaching, and long-lasting than those at work in the privatization of tap water.

In this article, we have made two principal arguments. First, bottled water requires a reconsideration of the dominant ways in which scholars have so far conceptualized the privatization and commodification of water. We have argued that bottled water represents a more perfect commodity for capital accumulation, due to several intrinsic and extrinsic characteristics. It differs in important ways from municipal tap water systems - including its lower sunk costs and investment requirements, its greater price elasticity, and its defiance of water's locality - and these differences enable bottled water to escape many of the obstacles to accumulation posed by private operation of the massive piped water treatment and supply networks originally built by governments in the $19^{\text {th }}$ and $20^{\text {th }}$ centuries. However, without the political-economic and cultural developments that have facilitated bottled water's rapid riselifestyle shifts driving demands for convenience; neoliberal economic globalization and deregulation permitting the expansion of transnational firms; and weakened states increasingly incapable of defending public goods - it would likely not be nearly as ubiquitous today. These points obligate us to consider how the process of commodification unfolds differently in distinct contexts, and what kinds of developments permit capital to surmount structural barriers or limits to accumulation, as well as how social movements might most effectively respond to such developments. They also raise questions about the implications of a broad societal move toward such individualized, market-based approaches to meeting human needs.

Second, we have argued that there is an important, even synergistic, relationship between expansion of the private commodity of bottled water and the deterioration of public tap water systems. The fates of these two modes of water provision are closely linked. "A new conflict 
has been created," writes Opel (1999: 75), "between a previous public project to create better water and a new corporate product that claims greater purity through patented processes." Yet beyond simply exploiting public fears in order to increase sales, the industry's actions help to create a zero-sum game. While the majority of Northern citizen-consumers presently drink both private and public water, their choice to do the former contributes to the weakening of the latter, and of public goods and public life more broadly.

Similarly, on a global level, dis- or under-investment in safe public drinking water supply renders water more amenable to commodification by the bottling industry, but less accessible to the majority of humanity, to whom it is essential for life. The inverse applies as well. "If everyone on the planet had access to affordable safe tap water," argues Gleick (2010: 175), "bottled water use would be seen as unnecessary."

The local and supra-local movements opposing bottled water siting and consumptionsuch as the two communities profiled above-exemplify Polanyian counter-movements in the challenges and obstacles they pose to expansion of the fictitious commodity of water. While Polanyi likely would not have foreseen the conversion of water into a mass-market commodity via bottling, his incisive arguments for the rolling back of market power in relation to fictitious commodities clearly apply to this context. Several observers have employed the concept of "decommodification" to characterize these challenges, expanding upon Esping-Andersen's original use of the term as a response to the commodification of labor power (Bond 2005; Laxer and Soron 2006; Vail 2010)9. Kloppenburg (2010) adopts the term "repossession" to describe such movements, emphasizing their opposition to the dynamics of accumulation by dispossession.

\footnotetext{
${ }^{9}$ Vail (2010: 313) defines decommodification as "any political, social, or cultural process that reduces the scope and influence of the market in everyday life."
} 
In closing, we find it valuable to take a view of this issue that acknowledges the profound ecological and social-justice costs of bottled water's continued worldwide growth. Given the enormous energy expenditures, carbon emissions, and pollution problems generated by the production and disposal of hundreds of billions of single-use plastic bottles annually — when a far lower-impact alternative (the tap) is readily available in many cases-few other commodities illustrate the notion of unsustainability quite so dramatically. Considering that the continued growth of this commodity threatens the project of universal safe public drinking water provision, a compelling case could be made for greatly restricting its production and sale, except in natural disasters and emergencies or in settings where clean tap water is unavailable.

By contesting the bottling of local water by transnational firms and by advocating for policy and cultural change to take back the tap, communities and activists involved in the bottled water issue in both North and South are acting on the terrain of decommodification and repossession in efforts to raise barriers to capital accumulation. In doing so, they are complicating prevailing understandings of privatization, and rendering the fictitious, yet quite real, commodity of bottled water somewhat less perfect. 


\section{REFERENCES}

Ahlers, Rhodante. 2010. "Fixing and Nixing: The Politics of Water Privatization." Review of Radical Political Economics 42(2): 213-230.

Bakker, Karen. 2005. "Neoliberalizing Nature? Market Environmentalism in Water Supply in England and Wales." Annals of the Association of American Geographers 95(3): 542565.

-. 2010. Privatizing Water: Governance Failure and the World's Urban Water Crisis. Ithaca, NY: Cornell University Press.

Ball, Deborah. 2010. "Bottled Water Pits Nestlé vs. Greens." The Wall Street Journal, May 25.

Barlow, Maude. 2007. Blue Covenant: The Global Water Crisis and the Coming Battle for the Right to Water. New York: The New Press.

Barlow, Maude and Tony Clarke. 2002. Blue Gold: The Fight to Stop the Corporate Theft of the World's Water. New York: New Press.

Beverage Marketing Corporation. 2010, "Bottled Water Confronts Persistent Challenges, New Report From Beverage Marketing Corporation Shows." Retrieved August 30, 2011 (http://www.beveragemarketing.com/?section=pressreleases).

Bond, Patrick. 2005. "Globalisation/Commodification or Deglobalisation/Decommodification in Urban South Africa." Policy Studies 26(3/4): 337-358.

Boreal Water News. 2010. "Global Bottled Water Market to Reach $\$ 65.9$ Billion by 2012, According to a New Report by Global Industry Analysts, Inc." Retrieved August 30, 2011 (http://www.borealwater.com/boreal_water_news/2010/06/global-bottled-watermarket-to.php?var=news).

Castree, Noel. 2008. "Neoliberalising Nature: Processes, Effects, and Evaluations." Environment and Planning $A$ 40: 153-173.

Castro, José Esteban. 2007. "Poverty and Citizenship: Sociological Perspectives on Water Services and Public-Private Participation." Geoforum 38: 756-771.

—. 2008. "Water Struggles, Citizenship and Governance in Latin America." Development 51:7276.

Clarke, Tony. 2007. Inside the Bottle: An Exposé of the Bottled Water Industry (Revised). Toronto: Canadian Centre for Policy Alternatives.

Conca, Ken. 2008. "The United States and International Water Policy." Journal of Environment \& Development 17(3): 215-237.

Conlin, Michelle. 2008a. "A Community Goes Up_And Wins a Round-Against Nestle." Business Week, May 28.

- 2008b. "A Town Torn Apart by Nestlé." Business Week, April 16.

Correll, DeeDee. 2009. "Nestlé Wins Approval to Tap Colorado Ground Water." Los Angeles Times, August 20.

Dilworth, Richardson. 2007. "Privatization, the World Water Crisis, and the Social Contract." PS, Political Science \& Politics 40(1): 49-54.

Driessen, Travis. 2008. "Collective Management Strategies and Elite Resistance in Cochabamba, Bolivia." Development 51(1): 89-95.

DuPuis, Melanie. 2002. Nature's Perfect Food: How Milk Became America's Drink. New York: NYU Press.

Esterl, Mike. 2006. "Dry Hole: Great Expectations for Private Water Fail to Pan Out." Wall Street Journal, June 26. 
Environmental Working Group. 2008. "Bottled Water Quality Investigation: 10 Major Brands, 38 Pollutants." Environmental Working Group, Washington, DC.

Food and Water Watch. 2008. "Faulty Pipes: Why Public Funding-Not Privatization-Is the Answer for U.S. Water Systems." Food and Water Watch, Washington, DC.

—. 2010a. "Bottling Our Cities' Tap Water: Share of Bottled Water from Municipal Supplies Up 50 Percent." Food and Water Watch, Washington, DC.

—. 2010b. "Trends in Water Privatization: The Post-Recession Economy and the Fight for Public Water in the United States." Food and Water Watch, Washington, DC.

Gentile, Annie. 2008. "Mayors Push Benefits of Cities' Tap Water." American City \& County 123(9): 18-20.

Girard, Richard. 2009. "Bottled Water Industry Targets a New Market: The Global South." AlterNet, June 15.

Girard, Richard and Erika Shaker. 2008. "Bottled Up or Tapped Out: Where Have all the Water Fountains Gone?" Academic Matters: The Journal of Higher Education (November).

Glassman, Jim. 2006. "Primitive Accumulation, Accumulation by Dispossession, Accumulation by 'Extra-Economic' Means." Progress in Human Geography 30(5): 608-625.

Gleick, Peter H. 2010. Bottled and Sold: The Story Behind Our Obsession with Bottled Water. Washington, DC: Island Press.

Gleick, Peter H. and H. S. Cooley. 2009. "Energy Implications of Bottled Water." Environmental Research Letters 4(1): DOI: 10.1088/1748-9326/4/1/014009.

Gleick, Peter H., Heather Cooley, David Katz, et al. 2007. The World's Water, 2006-2007: The Biennial Report on Freshwater Resources. Washington, DC: Island Press.

Goldman, Michael. 2005. Imperial Nature: The World Bank and Struggles for Social Justice in the Age of Globalization. New Haven: Yale University Press.

—. 2007. "How "Water for All!'” Policy Became Hegemonic: The power of the World Bank and its Transnational Policy Networks." Geoforum 38: 786-800.

Hall, Noah. 2009. "Protecting Freshwater Resources in the Era of Global Water Markets: Lessons From Bottled Water." University of Denver Water Law Review 13(1): 1-53.

Harvey, David. 2003. The New Imperialism. New York: Oxford University Press.

Kessides, Ioannis N. 2005. "Infrastructure Privatization and Regulation: Promises and Perils." The World Bank Research Observer 20(1): 81-108.

Kinchy, Abby, Daniel Kleinman, and Robyn Autry. 2008. "Against Free Markets, Against Science? Regulating the Socio-Economic Effects of Biotechnology." Rural Sociology 73(2): 147-179.

Kloppenburg, Jack R. 2004. First the Seed: The Political Economy of Plant Biotechnology, 1492-2000 (2nd ed.). Madison: University of Wisconsin Press.

—. 2010. "Impeding Dispossession, Enabling Repossession: Biological Open Source and the Recovery of Seed Sovereignty." Journal of Agrarian Change 10(3): 367-388.

Laxer, Gordon and Dennis Soron. 2006. Not for Sale: Decommodifying Public Life. Peterborough, Canada: Broadview.

Lobina, Emanuele and David Hall. 2007. "Water Privatisation and Restructuring in Latin America, 2007." Public Services International Research Unit (PSIRU), London.

Loftus, Alex. 2009. "Rethinking Political Ecologies of Water." Third World Quarterly 30(5): 953-968.

Mann, Susan A. and James M. Dickinson. 1978. "Obstacles to the Development of a Capitalist Agriculture.” Journal of Peasant Studies 5(4): 466-481. 
Marx, Karl. 1867. Capital: A Critique of Political Economy. Chicago: Charles H. Kerr \& Co. Mascarenhas, Michael and Lawrence Busch. 2006. "Seeds of Change: Intellectual Property Rights, Genetically Modified Soybeans and Seed Saving in the United States." Sociologia Ruralis (46): 2.

McMichael, Philip. 2011. Development and Social Change (5th edition). Newbury Park, CA: Pine Forge Press.

Natural Resources Defense Council. 1999. "Bottled Water: Pure Drink or Pure Hype?" Natural Resources Defense Council, Washington, DC.

Opel, Andy. 1999. "Constructing Purity: Bottled Water and the Commodification of Nature." Journal of American Culture 22(4): 67-76.

Packaging Digest 2010. "Asia Helps Bottled Water in Global Recession." Packaging Digest, January 15.

Parag, Yael and J. T. Roberts. 2009. "A Battle Against the Bottles: Building, Claiming, and Regaining Tap-Water Trustworthiness." Society \& Natural Resources 22(7): 625-636.

Pechlaner, Gabriela and Gerardo Otero. 2010. "The Neoliberal Food Regime: Neoregulation and the New Division of Labor in North America." Rural Sociology 75(2): 179-208.

Pinsent Masons. 2011. Pinsent Masons Water Yearbook 2010-2011. London: Pinsent Masons.

Polanyi, Karl. 1944. The Great Transformation. Boston: Beacon Press.

Prasad, Naren. 2006. "Privatisation Results: Private Sector Participation in Water Services After 15 Years." Development Policy Review 24(6): 669-692.

Raman, K. Ravi. 2010. "Transverse Solidarity: Water, Power, and Resistance." Review of Radical Political Economics 42(2): 251-268.

Roberts, Adrienne. 2008. "Privatizing Social Reproduction: The Primitive Accumulation of Water in an Era of Neoliberalism." Antipode 40(4): 535-560.

Rodwan, John G. 2011. "Bottled Water 2010: The Recovery Begins: U.S. and International Developments and Statistics." Bottled Water Reporter 51(3): 11-17.

Shiva, Vandana. 2008. "From Water Crisis to Water Culture." Cultural Studies 22: 498-509.

Snitow, Alan, Deborah Kaufman, and Michael Fox. 2007. Thirst: Fighting the Corporate Theft of our Water. San Francisco: Wiley \& Sons.

Spronk, Susan and Jeffery R. Webber. 2007. "Struggles against Accumulation by Dispossession in Bolivia: The Political Economy of Natural Resource Contention." Latin American Perspectives 34(2): 31-47.

Stephenson, John B. 2009. "Bottled Water: FDA Safety and Consumer Protections are Often Less Stringent Than Comparable EPA Protections for Tap Water." U.S. General Accounting Office, Washington, DC.

Swyngedouw, Erik. 2005. "Dispossessing H2O: The Contested Terrain of Water Privatization." Capitalism Nature Socialism 16(1): 81-98.

Szasz, Andrew. 2007. Shopping Our Way to Safety: How We Changed from Protecting the Environment to Protecting Ourselves. Minneapolis: University of Minnesota Press.

Vail, John. 2010. "Decommodification and Egalitarian Political Economy." Politics \& Society 38(3): 310-346.

Velasquez-Manoff, Moises. 2009. "Pressure Builds Over Bottled Water." Christian Science Monitor, October 23.

Vidal, John. 2005. "Flagship Water Privatisation Fails in Tanzania." The Guardian, May 25.

—. 2006. "Big Water Companies Quit Poor Countries. " The Guardian, March 22. 
Wilk, Richard. 2006. "Bottled Water: The Pure Commodity in the Age of Branding." Journal of Consumer Culture 6(3): 303-325.

World Bank. 2005. "Infrastructure Development: The Roles of the Public and Private Sectors;

World Bank Group's Approach to Supporting Investments in Infrastructure." World Bank, Washington, DC. 